\title{
Pharmacognostical, Phytochemical and Antibacterial Studies on the Leaves of Ocimum tenuiflorum Linn. in Cuba
}

\author{
Eva Salas Olivet \\ Institute of Foods and Pharmacy, La Coronela, La Lisa, La Habana, Cuba \\ Tel: 53-7271-6110 E-mail: evaso@ifal.uh.cu \\ José González (Correspondence author) \& Armando Cuéllar \\ Department of Pharmacy, Faculty of Pharmacy and Foods, Havana University, Cuba \\ Tel: 53-7262-6664Ｅ-mail: jgyaque@ifal.uh.cu
}

\author{
Max Monan \\ ARVARNAM, Martinica, France \\ Yuliamny Adames \\ Finlay Institute, BioCubaFarma, Havana, Cuba \\ Roberto A. Ramírez \\ Western Medication Enterprise, BioCubaFarma, Havana, Cuba
}

Ellis M. García

National Normalization Office, Ministry of Sciences, Technology and Environmental, Cuba

Received: November 8, 2016 Accepted: December 17, 2016 Published: December 27, 2016 doi:10.5296/jas.v5i1.10512

URL: http://dx.doi.org/10.5296/jas.v5i1.10512

\begin{abstract}
Towards authentication and quality assurance of medicinal plants, pharmacognostic, physicochemical, phytochemical and preliminary antibacterial studies of the leaves of Ocimum tenuiflorum Linn, were carried out. The macroscopic evaluation revealed characters
\end{abstract}




\section{Macrothink}

Journal of Agricultural Studies

ISSN 2166-0379

2017, Vol. 5, No. 1

that are of diagnostic value and useful in authentication of the plant. The physicochemical analyses reveals values for moisture content (12.46\%), alcohol extractive $(0.5 \%)$, and total ash $(11.5 \%)$ which are within the World Health Organization (WHO) standards for crude drug from medicinal plants, except the last one. Phytochemical screening for secondary metabolites revealed the presence of fats, alkaloids, saponins, triterpens/steroids, reductants sugars, flavonoids, free aminoacids or amines, quinones, anthocyanins and mucilage, and phenolic compounds, while resins and balsams, coumarins and tannins were absent. Information obtained from these studies can be used as markers in the identification and standardization of this plant as a herbal remedy and also towards monograph development on the plant.

Keywords: leaves, physicochemical, phytochemical studies, Ocimum tenuiflorum.

\section{Introduction}

The specie Ocimum tenuiflorum Linn, belong to the botanical family of Lamiaceae, commonly known as "Albahaca morada" which it is of a great importance for its therapeutic potentials. O. tenuiflorum $\mathrm{L}$ is an herbal plant, original from the warm and tropical areas of India, distributed in Africa and southern Asia. The plant is also known as Ocimum sanctum or Tulsi. Known in India as "Incomparable", still Ayurvedic practitioners prescribed fresh plant to reestablish the health (Geeta et al., 2001).

Genus Ocimum is represented by more than 150 species of herbal plants, of which only 6 are present in Cuba: O. sanctum (Albahaca morada), O. basilicum (A. blanca), O. gratissimum (A. de clavo), O. micranthum (A. cimarrona), O. kilimandsharicum (A. alcanforada) and $O$. canum (A. velluda). O. sanctum is an annual or biannual plant, erect, very ramificated, 30-80 $\mathrm{cm}$ high, with green or purple leaves, strongly perfumed. Leaves are oval to elliptic, margin dentate, $3-5 \mathrm{~cm}$ long, tiny petioles, and apex obtuse or acute, base stretched or oval. Flowers are purple, solitary and multiples of ten, pedicels are shorter than leaves (2-3 $\mathrm{mm}$ long). Calyx from 4-5 cm long in fruit, 5-lobate. It smelled strongly aromatic and tasted slightly pungent and bitter (Roig, 1988) (Fig. 1).

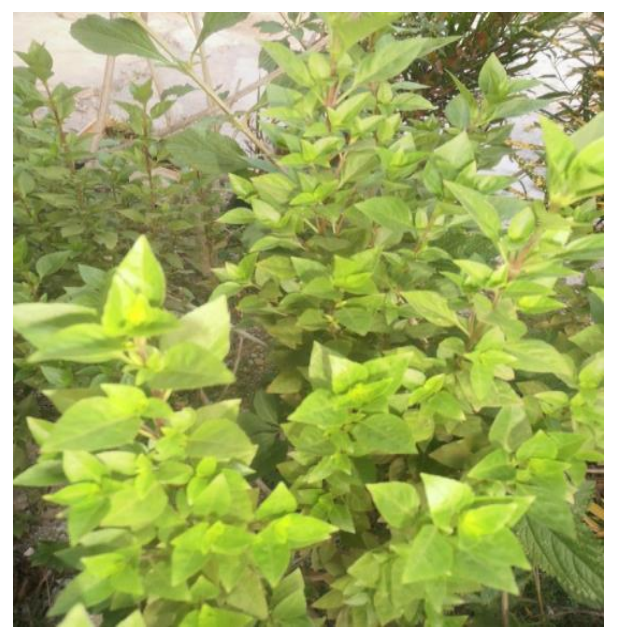

Figure 1. Plant of O. tenuiflorum Linn. 
The present study aimed at investigating the macromorphology, pharmacognostic evaluation and phytochemical screening of the leaves of Ocimum tenuiflorum L. towards standardization and monograph development.

\section{Material and Methods}

\subsection{Sample Collection and Processing}

The whole plant was collected from "Barros" Farm, located in Calzada de 10 de Octubre, near Café Colón, 10 de Octubre municipality, Havana City. The plant material was authenticated by Professor Dr. Jorge E. Gutiérrez Amaro, and identified at the herbarium of National Botany Garden of Havana, where the voucher specimen no. HAJB 8258788665, HFC series, has been deposited. After collection, vegetable material was washed with abundant water and suddenly introduced into sodium hypochlorite $1 \%$ during 5 minutes and once again, washing with abundant water. The isolate leaves were dried in an oven MLW WSU 100 with controlled temperature, at $40^{\circ} \mathrm{C}$, during 5 days. The powdered sample (1-2 $\mathrm{mm}$ ) was stored in air tight container for the phytochemical analysis.

\subsection{Pharmacognostic Analysis}

\subsubsection{Macromorphology}

Macromorphological characters of the leaves like leaf shape, size, colour, texture, margin type, apex, base and petiole size, flower colour and length, etc., were observed. Measurements were carried out using line ruler. The macromorphological characteristic of the leaf was observed under the magnifying lens (10x).

\subsubsection{Physicochemical Analysis}

Physicochemical analyses were carried out on the powdered sample following standard methods (WHO, 1986; Miranda and Cuéllar, 2001). Moisture content (gravimetric indirect volatilization method), alcohol extractive value (30, 50 and $70 \% \mathrm{v} / \mathrm{v} / \mathrm{v})$ utilizing maceration method, and total ash value were tested for. All tests were done in triplicate.

The hydroalcoholic extracts at 30,50 and $70 \%$ were tested using fresh and dried leaves (70 \%) to get information about organoleptic characteristics, relative density, refraction index, $\mathrm{pH}$ and total solids (soluble extractives), filtered and concentrated using vacuum distillation.

\subsubsection{Phytochemical Screening}

Preliminary phytochemical investigations for secondary metabolites were carried out on the powdered sample of the leaves of $O$. tenuiflorum, one of them with green leaves and another one, with purple leaves, to compare possible differences using standard procedures (Miranda and Cuéllar, 2001). The metabolites tested for were carbohydrates, balsams, resins, saponins, sterols, triterpens, tannins, flavonoids, free aminoacids or amines, alkaloids, phenolic compounds, flavonoids and quinones.

\section{$2.3 \mathrm{HPLC} / \mathrm{UV} / \mathrm{MS}$ Conditions}

Analyses were run on an HPLC-System AZURA (Germany) coupled to UV-Vis AZURA 
UVD 2.1 L detector at $280 \mathrm{~nm}$, with a quaternary gradient low pressing pump AZURA P 6.1 L, an AZURA thermostat CT 2.1 and manual injector. The identification and integration of chromatographic peaks was done utilizing a compatible PC and a software ClarityChrom version 6.1.0.130 (KNAUER, Germany). The chromatographic separation to obtain the chemical profile from the total extract was made using a reverse fase column Eurospher C-18, $60 \AA$, $5 \mu \mathrm{m}$ (i.d), $250 \times 4 \mathrm{~mm}$ (Germany). Elution was performed at a flow rate of $\mathrm{mL} / \mathrm{min}$, using as eluent (A) $\mathrm{H} 2 \mathrm{O} 0.1 \%$ and eluent (B) $\mathrm{ACN} 0.1 \%$. All solvents were degassing previously before used in an ultrasonic bath without filtration. A gradient of $\mathrm{A}=15.0 \%$ and $\mathrm{B}$ $=85.0 \%$ during $30 \mathrm{~min}$, was followed by holding the gradient during $37 \mathrm{~min}$, then changing the gradient of $\mathrm{A}=50.0 \%$ and $\mathrm{B}=100.0 \%$ during 10 min and reversing to $\mathrm{A}=50.0 \%$ and $\mathrm{B}$ $=0.0 \%$ during $5 \mathrm{~min}$, reequilibrating during $5 \mathrm{~min}$ at a temperature of $25{ }^{0} \mathrm{C}$. In the realized analysis were used the elaborated extracts with ethanol and the dried leaves at 30,50 and $70 \%(\mathrm{v} / \mathrm{v} / \mathrm{v})$.

\subsubsection{Test to the determination of antimicrobial susceptibility in vitro}

To evaluate hydroalcoholic extracts antibacterial activity of $O$. tenuiflorum, disc diffusion method was carried out using $8 \mathrm{~mm}$ filter discs (Kirby-Bauer method) developed to both extracts with fresh and dried plant, and the rotvapored extracts until dried, them extracting concentrated, weighted to get the work dilutions. $8 \mathrm{~mm}$ filter discs were sterilized before deposited $5 \mu \mathrm{L}$ of each aseptic solution. 4 serial solutions (1:2) of each obtained extract at a concentration of $0.42 \mathrm{~g} / \mathrm{mL}$ were developed.

\subsubsection{Bacteria strains, Disc-diffusion method and Microdilution test}

Gram-negative bacteria: Escherichia coli (ATCC 25922), Bacillus cereus (ATCC 11778), Bacillus subtilis (ATCC 6633) and Gram-positive bacteria: Staphylococcus aureus (ATCC 25923). The microorganisms were obtained from the Mycological Laboratory, BioCen, Bejucal, Mayabeque province, Cuba. The microorganisms were replanted into Brain-heart infusion, incubated at $35 \pm 2{ }^{\circ} \mathrm{C}$ during 16 hours. The antibacterial activity was also evaluated by the microdilution method (Hanel and Raether, 1988; Espinel-Ingroff, 2001). The bacterial suspensions were adjusted visually to a turbid standard $0.5 \mathrm{McF}$ arland scale with sterile saline to a concentration of $2 \times 10^{6} \mathrm{CFU} / \mathrm{mL}$. The inoculate were prepared daily and stored at $+4^{\circ} \mathrm{C}$ until use. Dilutions of the inoculate were cultured on solid medium to verify the absence of contamination and to check the validity of the inoculum.

The minimum inhibitory and bactericidal concentrations (MICs and MBCs) were determined using 96-well microtitre plates. Extracts to be investigated were dissolved in 5\% DMSO solution containing $0.1 \%$ Tween $80(\mathrm{v} / \mathrm{v})(5 \mathrm{mg} / \mathrm{mL})$ and added in TSB medium $(100 \mu \mathrm{L})$ with bacterial inoculum $(1.0 \times 105 \mathrm{CFU} /$ well $)$ to achieve the wanted concentrations. The microplates were incubated at Rotary shaker $(160 \mathrm{rpm})$ for $24 \mathrm{~h}$ at $37^{\circ} \mathrm{C}$. The lowest concentrations without visible growth (at the binocular microscope) were defined as MICs. The MBCs were determined by serial sub-cultivation of $5 \mu \mathrm{L}$ into microliter plates containing $95 \mu \mathrm{L}$ of broth per well and further incubation for $24 \mathrm{~h}$. The lowest concentration with no visible growth was defined as the $\mathrm{MBC}$, indicating $99.5 \%$ killing of the original inoculum. The optical density of each well was measured at $655 \mathrm{~nm}$ by ELISA microplate reader 


\section{Ml Macrothink}

Journal of Agricultural Studies

ISSN 2166-0379

2017, Vol. 5, No. 1

(Bio-Rad Laboratories, Hercules, CA) and the results were processed with Microplate manager 4.0 (Bio-Rad Laboratories, Hercules, CA) and compared with a blank and with positive control. Penicillin G 10 IU and azithromycin $15 \mu \mathrm{L}$ (LIOFILCHEM, Bacteriology Product, Italy) were used as positive controls $(1 \mathrm{mg} / \mathrm{mL}$ in sterile physiological saline) (Sokovic et al., 2010). Solution of 5\% DMSO was used as negative control.

\section{Results and Discussion}

\subsection{Macroscopical Identification}

The morphological appearance of leaves was size: $2-3.5 \mathrm{~cm}$ long and 1-2 $\mathrm{cm}$ wide. The shape was peciolated, acute-obtuse, rhomboid-ovate, dentate, palm nerve, surface straight and flat and the color was intense green with aromatic odor (Fig. 2).
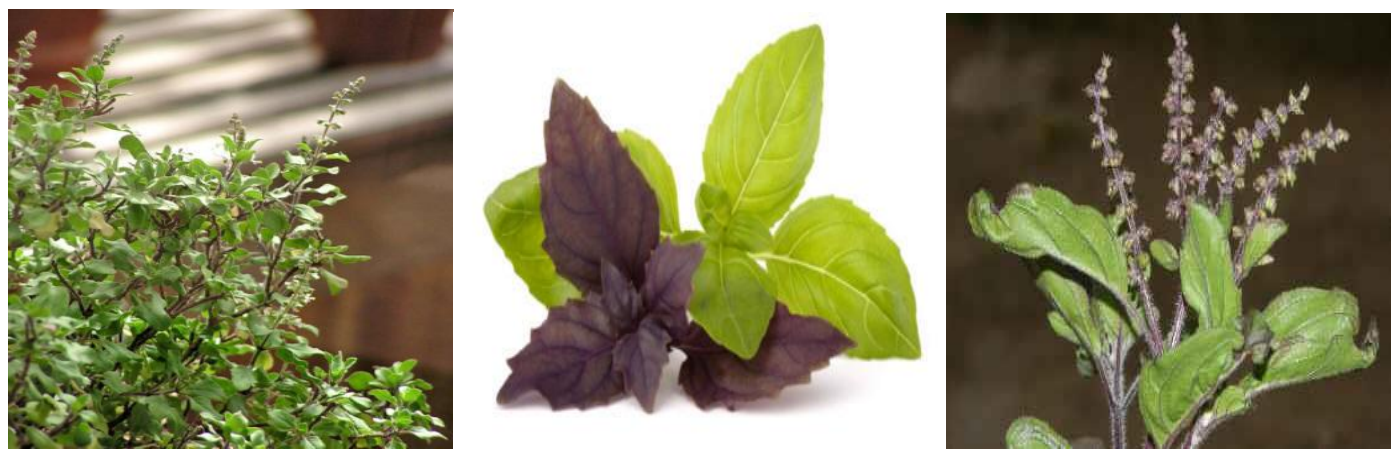

Figure 2. Leaves of O. tenuiflorum Linn.

\subsection{Physicochemical Studies}

\subsubsection{Phytochemical Screening}

Preliminary phytochemical screening showed the presence of at least 12 different chemical components in the extracts of the leaves (fresh and dried) with two different colors: green and purple (Table 1).

Table 1. Phytochemical analysis of $O$. tenuiflorum Linn.

\begin{tabular}{|l|l|c|}
\hline Test for constituent groups & \multicolumn{1}{|c|}{ Name of the test } & $70 \%$ Ethanol extract \\
\hline Flavonoids & Shinoda & + \\
\hline Volatile oil & Microsublimation-vanillic & + \\
\hline Alkaloid & Dragendorff's reagent test & + \\
\hline Saponins & Foam test $(2$ mm for 2 min $)$ & + \\
\hline Tannins/phenolic compounds & Ferric chloride test & + \\
\hline Free amino acid/amines & Ninhydrin & + \\
\hline Fats & Sudan IV & + \\
\hline Quinones & Börntrager & + \\
\hline Triterpens and steroids & Liebermann-Burchard & + \\
\hline Anthocyanins & HCl conc./amilic alcohol & + \\
\hline Mucilage & Soluc. at temp. $0-5{ }^{\circ} \mathrm{C}$ & + \\
\hline Reductants sugars & Fehling test & + \\
\hline
\end{tabular}


The behavior of the powder, phytochemical examination of the ethanolic extracts indicate the presence of tannins, alkaloids, phenolic compounds, flavonoids, sugars, saponins, mucilage, triterpens and steroids, fats or volatile oil, quinones, anthocyanins and free amino acids or amines. Is obvious the absent of coumarins, cyanogenetic glycosides, cathequins and resins. A detailed information will be useful for the development of standardization parameters, isolation of phytoconstituents, screening of preclinical and clinical investigation, manufacturing of formulations and also distinguishing it from its closely related species.

\subsubsection{Physicochemical Characteristics}

Several studies suggest that adulteration and misidentification of crude drugs can cause serious health problems to consumers and legal challenges for the pharmaceutical industries. The macroscopic and microscopic characters of any plant drug are considered to be the preliminary steps for establishing their quality control profile. As per the guidelines of WHO, pharmacognostical standards should be proposed as a protocol for the diagnosis and authentication of the herbal drugs (Pramanick, 2016).

An excess of water in medicinal plant materials will encourage microbial growth, the presence of fungi or insects, and deterioration following hydrolysis. Limits for water content should therefore be set for every given plant material. This is especially important for materials that absorb moisture easily or deteriorate quickly in the presence of water. Moisture content $(12.46 \%)$ was less than the limited index (8-14 \%), explaining the weather in Barros Farm, it can reach the standard. Total ash $(11.5 \%)$ was higher than the standard of Pharmacopoeia of the United States of America (USP XXXIII, 2010) for medicinal plants (3-6 \%), although The Pharmacopoeia of the

People's Republic of China permits a limit value for herb of $15.0 \%$ (Commission, 2015). Determination of extractable matter in alcohol at $70 \%$ was $0.5 \%$ (Table 2).

Table 2. Physicochemical characteristics of $O$. tenuiflorum Linn.

\begin{tabular}{|c|c|}
\hline Physicochemical parameter & values $(\% \mathrm{w} / \mathrm{w})$ \\
\hline Moisture content & 12.46 \\
\hline Total ash & 11.5 \\
\hline Extractable matter & 0.5 \\
\hline
\end{tabular}

\subsubsection{Physicochemical Characteristics of Extracts}

In order to determine the physicochemical parameters of extracts were evaluated the following parameters: organoleptic characteristics, relative density, refraction index, $\mathrm{pH}$, and total solids. All determinations were done to the elaborated extracts at 30,50 and $70 \%$ with dried plant. Only was used fresh plant in an extract at $70 \%$.

Table 3 reflexes the results on organoleptic characteristics and pharmacognostic parameters of the assayed extracts. The extract elaborated at $30 \%$ with dried plant shows differences in two evaluated variables: color and transparence. The parameters are indicative of the extract quality and the stability of them, because the values keep a stretch relation with the chemical composition of the exanimated sample. $\mathrm{pH}$ offer information about the acid or basic character 


\section{Ml Macrothink}

Journal of Agricultural Studies

ISSN 2166-0379

2017, Vol. 5, No. 1

into a solution, necessary to guaranties the extracts stability. In this case, the $\mathrm{pH}$ indicates that extracts have a hydrogen ionic concentration near to neutral or weak acidic. The best obtained value of soluble solids indicate that the better extract was those elaborated with a dried plant at $70 \%$ hydroalcoholic solution in which is possible inferred that the amount of secondary principles is biggest.

Table 3. Organoleptic characteristics of extracts.

\begin{tabular}{|c|c|c|c|c|}
\hline Characteristics & $\mathbf{5 0} \%$ & $\mathbf{3 0} \%$ & $\mathbf{7 0} \%$ & $\mathbf{7 0 ~ \%}^{*}$ \\
\hline Color & Intense green & Red brown & Intense green & Intense green \\
\hline Transparence & Translucid & Opaque & Translucid & Translucid \\
\hline Particulates & - & - & - & - \\
\hline Separation in layers & - & - & - & - \\
\hline Odor & Characteristic & Characteristic & Characteristic & Characteristic \\
\hline Relative density $(\mathrm{g} / \mathrm{mL})$ & 0.1333 & 0.1374 & 0.1293 & 0.1291 \\
\hline Refraction index & 1.3498 & 1.3424 & 1.3582 & 1.3539 \\
\hline $\mathrm{pH}$ & 6 & 6 & 6 & 6 \\
\hline Soluble solids & 0.4 & 0.4 & 0.8 & 0.4 \\
\hline
\end{tabular}

*extract elaborated with fresh plant.

\subsubsection{HPLC-UV Profiles}

The chromatograms were developed with the hydroalcoholic extracts at 30, 50 and $70 \%$, respectively. The most quantity of components afford before $38 \mathrm{~min}$ and the chromatographic profiles show that the more intense peaks were registered before $22 \mathrm{~min}$, showing that the extraction procedure adopted is efficient for concentration of this class of compounds. The extracts at 50 and $70 \%$ shows biggest amount of peaks before $21 \mathrm{~min}$, being the peak at 18.67 min the most important component which is could be the most interesting peak to elucidate its structural formula by MS or NMR (Figures 3, 4 and 5).

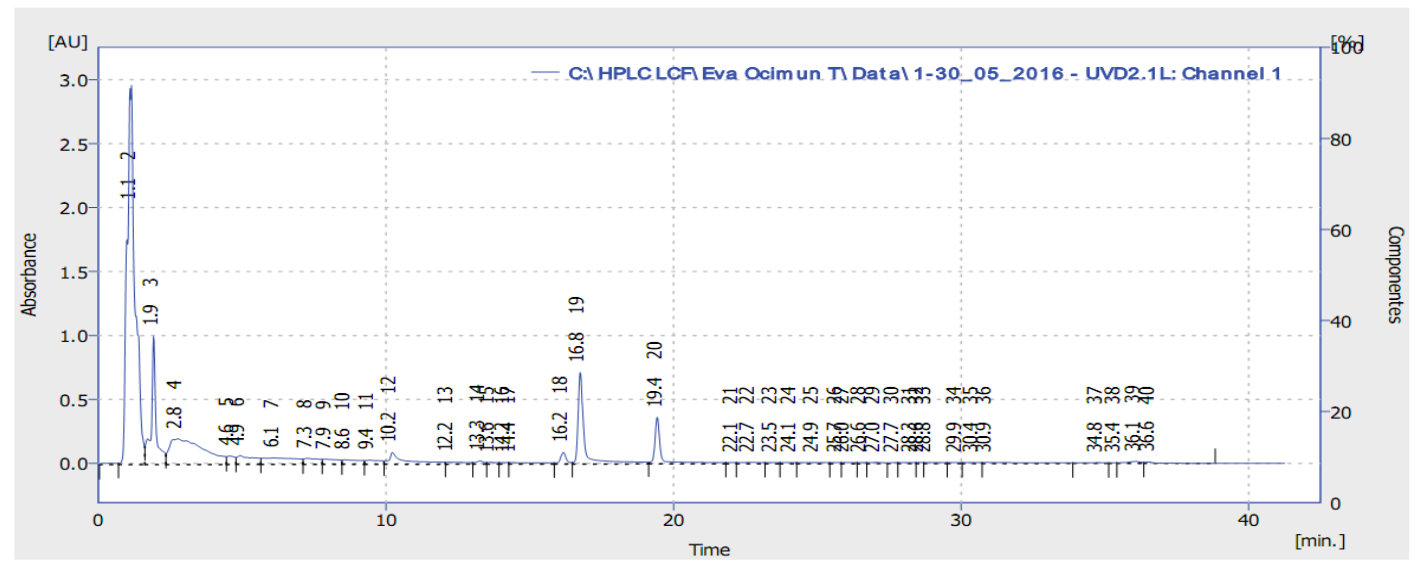

Figure 3. HPLC-UV chromatogram of ethanolic extract at $30 \%$. 


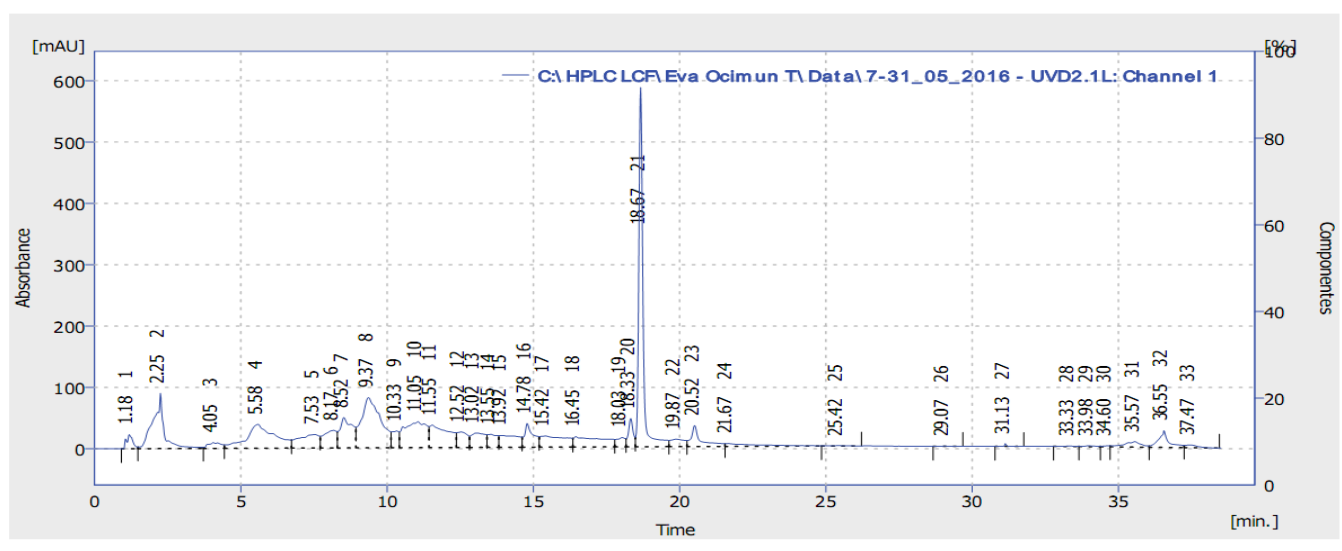

Figure 4. HPLC-UV chromatogram of ethanolic extract at $50 \%$.

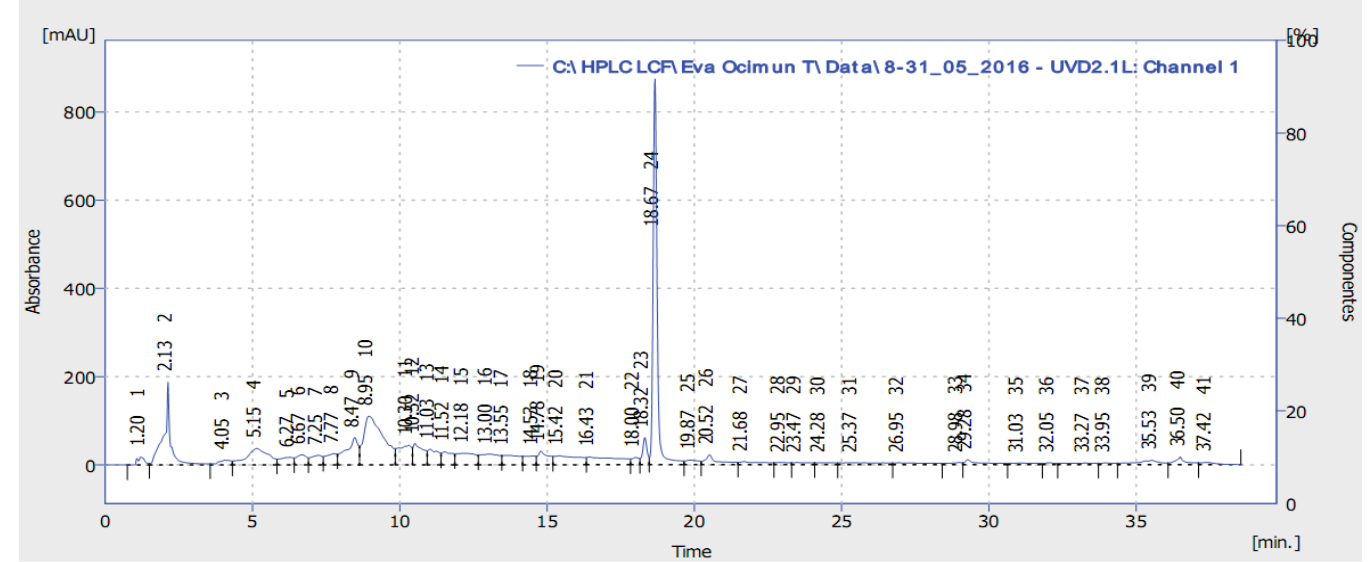

Figure 5. HPLC-UV chromatogram of ethanolic extract at $70 \%$.

This solvent system showed good resolution of peaks within specific time and was finally selected as mobile phase system for analysis. The results allow infers that until now, the chemical constituents in this plant are included in the range of medium and high polarity.

\subsection{Antimicrobial Susceptibility Test}

Singh et al., 2005, found antibacterial activity in this plant without specification of the method of extraction that they used. To checking the behavior, this test was done twice: with ethanolic extracts at 30, 50, and $70 \%$ in fresh and dried plant utilizing maceration method. In the first case, the results show that $B$. cereus only was inhibited with the ethanolic extract at $70 \%$, giving a $9 \mathrm{~mm}$ diameter of the growth inhibition zone. The rest of assayed microorganism shown negative results.

The second case, to determine the antimicrobial activity with the extracts of the dried plant, the extracts was rot evaporated to eliminate the alcohol presence. The results showed that $B$. cereus gave positive in all dilutions at $70 \%$, with inhibition zones of $10,10,9$ and $8 \mathrm{~mm}$, and in the two first dilutions at 30 and $50 \%$ with inhibition zones of 7 and $10 \mathrm{~mm}$. B. subtilis in the first dilution of the three assayed extracts showed inhibition zones. No antibacterial 
activity was found in front of E. coli and S. aureus (Table. 4).

Table 4. In vitro antibacterial susceptibility assay.

\begin{tabular}{|c|c|c|c|c|c|c|c|c|c|c|c|c|}
\hline \multirow[t]{2}{*}{ Strains } & \multicolumn{4}{|c|}{$70 \%(0.42 \mathrm{~g} / \mathrm{mL})$} & \multicolumn{4}{|c|}{$50 \%(0.42 \mathrm{~g} / \mathrm{mL})$} & \multicolumn{4}{|c|}{$30 \%(0.428 \mathrm{~g} / \mathrm{mL})$} \\
\hline & 1 & 2 & 3 & 4 & 1 & 2 & 3 & 4 & 1 & 2 & 3 & 4 \\
\hline S. aureus & - & - & & - & - & & & - & - & & $\begin{array}{ll}- & -1 \\
-1\end{array}$ & \\
\hline B. cereus & + & + & + & + & + & + & - & - & + & + & - & - \\
\hline B. subtilis & + & - & - & - & + & - & - & - & + & - & - & - \\
\hline E. coli & - & - & - & - & - & . & - & - & - & - & - & \\
\hline
\end{tabular}

These results allow to inferred that the amount of secondary metabolites with antimicrobial activity, depending of the bacterias specie and the concentration of the active substances because no activity is appreciated in all assayed strains. In both assays, positive controls showed antibacterial activity under these conditions, and it is appreciated diffusion of the samples into Mueller-Hinton agar because of the hydrophilic character of the extracts.

\section{Conclusions}

Physicochemical parameters like ash values, moisture content are all indicators of quality herbal medicine, which help to determinate the physiological and non-physiological ash, possibility of microbial growth or contamination and presence of impurities respectively. The relative high total ash value $(11.5 \%)$ of $O$. tenuiflorum Linn. indicates that the crude drug contains plenty of physiological ash and the non-physiological content, it will affect the clinical efficacy of drugs, so it should pay attention to the control quality of medicinal materials in herbs production.

This research showed that, O. tenuiflorum Linn. can be identified by structural features or characteristics of leaves as distinctive identification character. Efforts have been made by the authors to bring out every detail on the macroscopical characters of the leaves of this medicinal plant. The study of pharmacognostical features had shown the standards, which will be useful for the detection of its identity and authenticity.

It provides reference basis for formulating quality standard of $O$. tenuiflorum L authenticity of medicinal herbs and resource utilization.

\section{Acknowledgements}

This work was technically supported by the Central Laboratory of Pharmacology at "Salvador Allende" Medical Faculty, in Havana City.

\section{Conflict of interest statement}

We declare that we have no conflict of interest. 


\section{Macrothink}

\section{References}

Commission CP. (2015). Pharmacopoeia of the People's Republic of China. Chinese Medical Science and Technology Press. Peking. p. 337.

Espinel-Ingroff, A. (2001). Comparation of the E-test with the NCCLS M38-P method for antifungal susceptibility testing of common and emerging pathogenic filamentous fungi. Journal of Clinical Microbiology, 39, 1360-1367.

Geeta, Vasudevan, D. M., Kedlaya, R., Deepa, S., Ballal, M. (2001). Activity of Ocimum sanctum (the traditional Indian medicinal plant) against the enteric pathogens. Indian J Med Sci., 55, 434-8, 472.

Hanel, H., \& Raether, W. (1988). A more sophisticated method of determining the fungicidal effect of water-insoluble preparations with a cell harvester, using miconazole as an example. Mycoses, 31, 148-154.

Miranda, M., \& Cuéllar, A. (2001). Manual de Practicas de Laboratorio. Farmacognosia y Productos Naturales. 1ra Edición. Editorial Félix Varela. La Habana, Cuba. pp. 34-73.

Pramanick, D. D. (2016). Pharmacognostic studies on the pseudobulb of Coelogyne cristata Lindl. (Orchidaceae) -An epiphytic orchid of ethno-medicinal importance. J Pharmacogn Phytochem, 5(1), 120-123.

Roig, J. T., \& Roig, J. T. (1988). Plantas medicinales, aromáticas o venenosas de Cuba. Editorial Científico Técnica, Cuba, 618-619.

Singh, S., Malhotra, M., \& Majumdar, D. K. (2005). Antibacterial activity of Ocimum sanctum L. fixed oil. Indian J Exp Biol., 43, 835-7.

Sokovic, M., Glamoclija, J., Marin, P. D., Brkic, D., \& van Griensven, L. J. (2010). Antibacterial effects of the essential oils of commonly consumed medicinal herbs using an in vitro model. Molecules, 15, 7532-7546.

USP 33-NF 28. (2010). Validation of compendia methods. United States Pharmacopoeial Convention, Rockville, MD, USA, 2748.

WHO (World Health Organization). (1998). Quality control methods for medicinal plant materials. Geneva. Typeset in Honk Kong. Printed in England. 95/10628-Best-set/Clays-6000

\section{Copyright Disclaimer}

Copyright for this article is retained by the author(s), with first publication rights granted to the journal.

This is an open-access article distributed under the terms and conditions of the Creative Commons Attribution license (http://creativecommons.org/licenses/by/4.0/). 